\title{
Physico Chemical and Biological Study on the Lentic Water Bodies of Palakkad, Kerala
}

\author{
Jipsa.J.R ${ }^{1}$, Divya.K.R ${ }^{2 *}$, Dr.S.Logaswamy ${ }^{1}$ And Dr.K.Manonmani ${ }^{2}$ \\ P.G. and Research Department of Zoology, \\ P.G. and Research Department of Botany, \\ Kongunadu Arts and Science College, Coimbatore 641029, Tamil Nadu, India
}

\begin{abstract}
The water analysis of physico-chemical and biological parameters is very important for public health studies. Ponds are found inside the temples or outside the temples.. However, temple ponds located outside the temples are used by peoples for bathing and even washing clothes. Limnological features of two such temple ponds, the Ramott pond and Guruswamiyar pond were undertaken in the present study. The biological parameters of the ponds were also made during the study. In the present investigation all the parameters showed higher values in Pond B compared to Pond A. All values are found to be within or less than the permissible limit. Both ponds showed an oligotrophic nature with the presence of poor nutrients and low vegetation. Both ponds are unpolluted fresh water bodies which have no chemical or sewage pollution.
\end{abstract}

Keywords: Pollution, Ramott, Guruswamiyar, Phytoplanktons, oligotrophic.

\section{Introduction}

Water supports life on earth and around which the entire fabric of life is woven. Ponds as source of water are of fundamental importance to man However pond may have been a natural water sources exploited by man at different time to meet different needs or may have been created for an altitude of different needs, eg: domestic or agricultural use for transport, defence, industrial use, social aggrandizement, swimming, fish farming (Ress et al., 1997).

Phytoplankton is the major primary producers in many aquatic systems and is important food source for other organisms (Sukumaran et al., 2008). Phytoplankton not only serve as a food for aquatic animals but also plays an important role in maintaining the biological balance and quality of water (Pandey et al., 1998).The productivity of fresh water community that determines the fish growth is regulated by the dynamics of its physico-chemical and biotic environment (Wetzel et al., 1983).Our present study is going to determine the physico chemical properties of pond water and the presence of phytoplankton, zooplankton and nekton.

The water analysis of physico-chemical and biological parameters is very important for public health studies. The studies are also main part of pollution studies in the environment.(Kot et al.,2000). Only a few studies (Anithakumari and Aziz, 1989; Maya et al., 2000, 2001; Prameela et al., 2001; Maya, 2002) are available on temple ponds of Kerala. Limnological features of two such temple ponds, the Ramott pond and Guruswamiyar pond were undertaken in the present study. The biological parameters of the ponds were also made during the study.

\section{Materials And Methods}

The study of Ramott pond was in the Palakkad district in Kerala.The Guruswamiyar pond is situated near the road side in Tattamangalam situated in Palakkad. The pond is used for washing, bathing and it is a main source for the irrigation purposes during summer season. The study was conducted during the period from October to January (2012-2013) by which temperature range was in between $21.8^{\circ} \mathrm{C}$ and $30^{\circ} \mathrm{C}$ and the rainfall is about 3.5 to $2111.4 \mathrm{~mm}$. The analysis of all parameters like "total solids, dissolved oxygen, free carbon dioxide, carbonate, bicarbonate, calcium, magnesium, chloride, sulphate, phosphate, nitrate, iron, silicate and biological oxygen demand were estimated in the laboratory following the standard methods of APHA (2005). Qualitative analysis of plankton and fishes were also made in both the ponds A and B. Plankton were studied under compound microscope and identified with the help of standard references (Adoni et al., 1985; Agarker et al., 1994).

\section{Results And Discussion}

During experimental period ( Oct. 2012 to Jan. 2013 ), the environmental temperature ranged between $19^{\circ} \mathrm{C}$ and $30^{\circ} \mathrm{C}$ in pond $\mathrm{A}$ and in pond $\mathrm{B}$, it was between $21^{\circ} \mathrm{C}$ and $31^{\circ} \mathrm{C}$. The highest air and water temperature value $\left(31^{\circ} \mathrm{C}\right.$ and $\left.26^{\circ} \mathrm{C}\right)$ was recorded in January in pond $\mathrm{B}$ and the lowest air and water temperature value $\left(23^{\circ} \mathrm{C}\right.$ and $20^{\circ} \mathrm{C}$ ) was recorded in pond $\mathrm{A}$ in November. The water temperature was consistently lower than the atmospheric temperature. Similarly the bottom water temperature was consistently lower than the surface water. 
$\mathrm{pH}$ values varied between 6.05 to7.45 in both $\mathrm{A}$ and $\mathrm{B}$ ponds. The maximum $\mathrm{pH}$ value was recorded $7.45 \pm 0.05$ in Pond A during November and minimum value was recorded $6.05 \pm 0.05$ in Pond B during January. In the present investigation the $\mathrm{pH}$ values were maximum during February and minimum during November. Besides the Pond A showing high $\mathrm{pH}$ value by comparing with Pond $\mathrm{B}$, while both ponds keeping same variation of $\mathrm{pH}$ from slightly acidic to slightly alkali during October to January.

Dissolved oxygen (DO) values ranged from $4.35 \mathrm{mg} / \mathrm{L}$ to $7.51 \mathrm{mg} / \mathrm{L}$ of which maximum value $(7.51 \pm$ $0.01 \mathrm{mg} / \mathrm{L})$ was noted in Pond A during October and minimum value $(4.35 \pm 0.05 \mathrm{mg} / \mathrm{L})$ in Pond B during October. Seasonally it is observed that DO values was more in October followed by November, December and less value was found in January in both the ponds. From these two ponds Pond A showed high oxygen level than Pond B. like that from each pond, bottom water showed high oxygen level than surface water.

Free Carbon dioxide is also one of the most important factors in aquatic habitat. It is highly soluble in water and is the main source of carbon path way in the nature. Plant absorbs the free carbon dioxide present in both atmosphere and water. Carbon dioxide in water bodies is contributed by the respiratory activity of the animals (Vasumathi et al., 2009).Free carbon dioxide in the present study varied from an average of 3.07 to $12.04 \mathrm{mg} / \mathrm{L}$. The lowest value ( $3.07 \pm 0.008 \mathrm{mg} / \mathrm{L}$ ) of free carbon dioxide was recorded in the surface water of Pond B in December month (winter season) where as the highest value $(12.04 \pm 0.05 \mathrm{mg} / \mathrm{L})$ was observed in the bottom water of Pond A during the period of January (pre summer season). Pond A showed consistently higher carbon dioxide than that of Pond B. Similarly the bottom water showed higher carbon dioxide than surface water. Seasonally carbon dioxide was more in January followed by December, November and less value was found in December in pond B.

Bicarbonate is an important parameter which contributes to alkalinity. But in the present study, the bicarbonate was found to be absent. Calcium was found higher $(28.33 \pm 2.886 \mathrm{mg} / \mathrm{L})$ in the bottom water of Pond B in January and lower $(8.33 \pm 2.886 \mathrm{mg} / \mathrm{L})$ in the surface water of Pond A in November. The calcium value was fluctuated from an average of 11.66 to $28.33 \mathrm{mg} / \mathrm{L}$ in Pond B and is higher when it is compared with Pond A. Seasonally calcium was more in January followed by October, December and less value was found in November in both ponds. The presence of calcium in the bottom water was consistently higher than the surface water in both ponds.

Salts of magnesium are found dissolved in all water. Rocks are the main source of magnesium. It is needed by all animals for phosphate transfer involving ATP and ADP. Magnesium was found maximum (23.33 $\pm 2.886 \mathrm{mg} / \mathrm{L})$ in the deeper part of Pond B in October and minimum $(3.33 \pm 2.886)$ in the surface water of Pond $\mathrm{A}$ in December. The magnesium value was fluctuated from an average of $8.33 \pm 2.886 \mathrm{mg} / \mathrm{L}$ to $23.33 \pm 2.886$ $\mathrm{mg} / \mathrm{L}$ in Pond B is higher when it is compared with Pond A. The magnesium level in the deeper water was consistently higher than that of surface water.

The ecological significance of chloride lies in its potential to regulate salinity of water and exert consequent osmotic stress on biotic communities (Shinde et al., 2011). Chloride showed high significant positive relationship with water temperature, bicarbonate and calcium. The chloride content in studied ponds varied from an average of 28.4 to $68.63 \mathrm{mg} / \mathrm{L}$ in Pond A, while in the Pond B its contents ranged from 35.5 to $85.2 \mathrm{mg} / \mathrm{L}$ respectively. The chloride content was lower than the maximum permissible limit prescribed by WHO standards (1993).It was observed that Pond B having more chloride content than Pond A, where as the bottom water having high chloride content than the surface water in both ponds during the study period. Seasonally, chloride was more in February followed by November, January and less value was found in December in both ponds.

Sulphate level was maximum $(98.16 \pm 1.44 \mathrm{mg} / \mathrm{L})$ in October at the bottom water of Pond B, while the minimum value $(60.72 \pm 1.639 \mathrm{mg} / \mathrm{L})$ was observed in surface water of Pond A during pre summer season (January). Seasonally it can be said that sulphate was more in October followed by November, December and less value was found in January in both ponds. Pond B was leading in the amount of sulphate than Pond A in all seasons. Bottom water was observed consistently higher sulphate than surface water. The overall value was less than maximum permissible limits $(500 \mathrm{mg} / \mathrm{L})$ according to WHO standards (1993), indicating that the pond was free from sulphate pollution during the study periods

The amount of Iron ranges from 0.00 to $0.57 \mathrm{mg} / \mathrm{L}$. More amount of iron was observed in January in the bottom water than that of pond $\mathrm{B}$. It was observed that there only a slight variations in the amount of iron present in pond A and B. It ranges from $0.27 \pm 0.015 \mathrm{mg} / \mathrm{L}$ to $0.59 \pm 0.01 \mathrm{mg} / \mathrm{L}$. The BOD in the water samples reveals the microorganisms present and their organic load in the water. In the present study BOD ranges from $1.12 \mathrm{mg} / \mathrm{L}$ to $1.98 \mathrm{mg} / \mathrm{L}$.

Qualitative analysis of plankton and fishes were made. A total of six types of species of phytoplankton in Pond A and five in Pond B were observed. Among the phytoplankton in both Pond A and B the blue green algae, Microcystis sp. was found to be in dominance. Chlorella sp., Spirogyra sp., Oscillatoria sp., Ulothrix sp., Merismopodia sp. were found to be next in dominance. About four types of zooplankton species were found in Pond A while, six were observed in Pond B. Zooplankton like Daphnia sp. and Cyclops sp. were found to be in 
appreciable quantities in both ponds. Calanus sp., Sagitta sp., Vorticella sp., Branchionus sp. were also found to be next in dominance.

A total of seven types of fishes in Pond A and six types in Pond B were observed during the period of study. Among the fishes, Danio malabaricus (Giant Danio) was commonly found in both ponds. Fishes like Catla catla, Cirrhina mrigala, Labeo rohita, Cyprinus carpio, Mugil cephalus and Channa marulius were also found to be occur in the study ponds by which Catla catla, Cirrhina mrigala, Labeo rohita are the cultured fishes in Pond A.
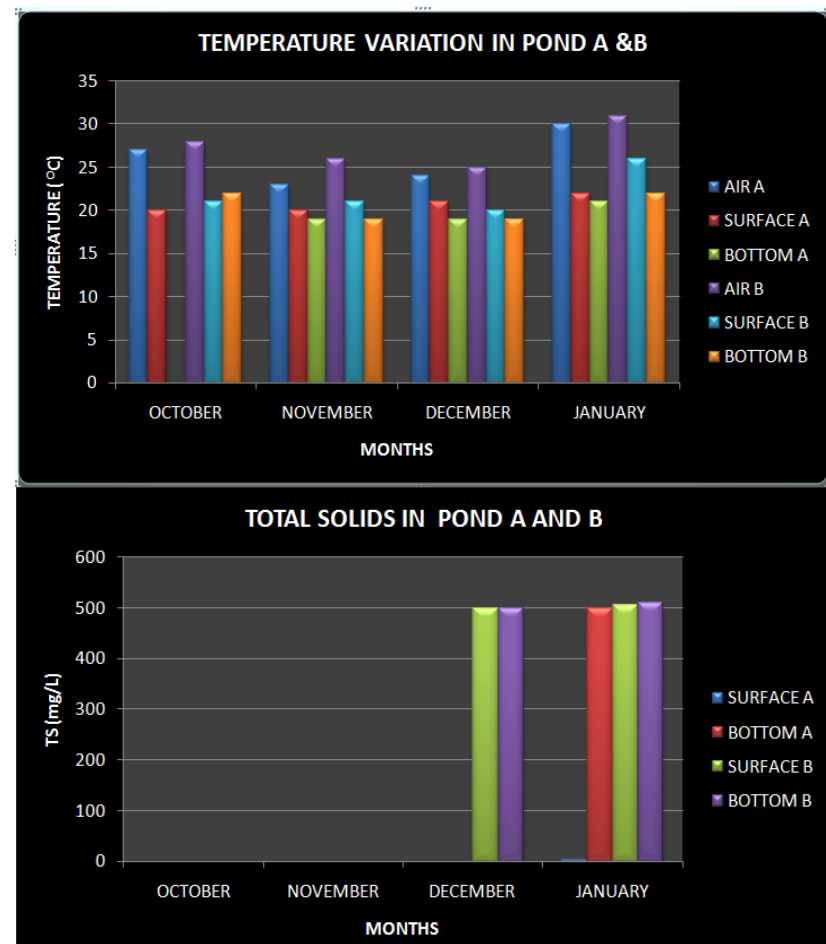

— SURFACEA

- BOTTOMA

- SURFACE B

च ВОтTOM B

pH IN POND A \& B

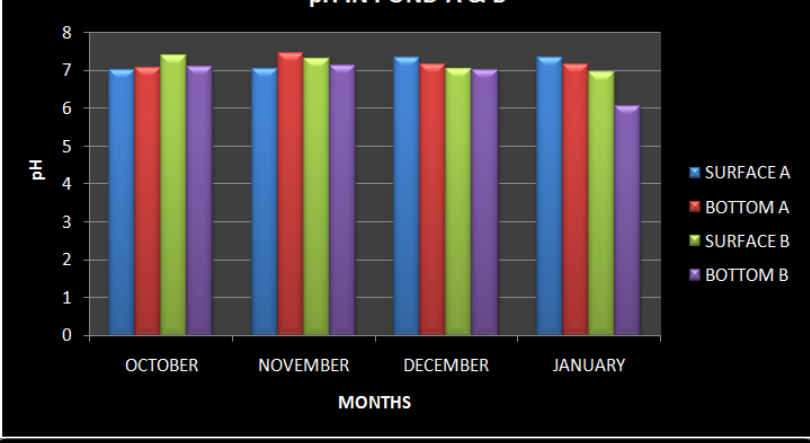

DISSOLVED OXYGEN IN POND A \& B

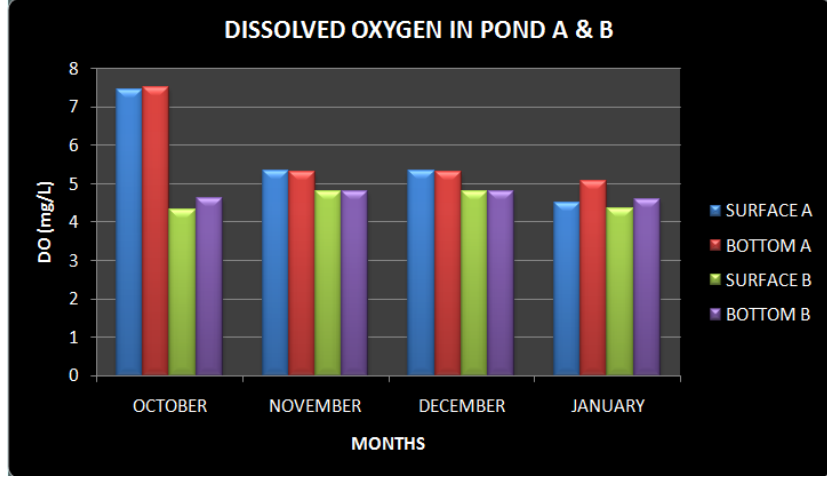




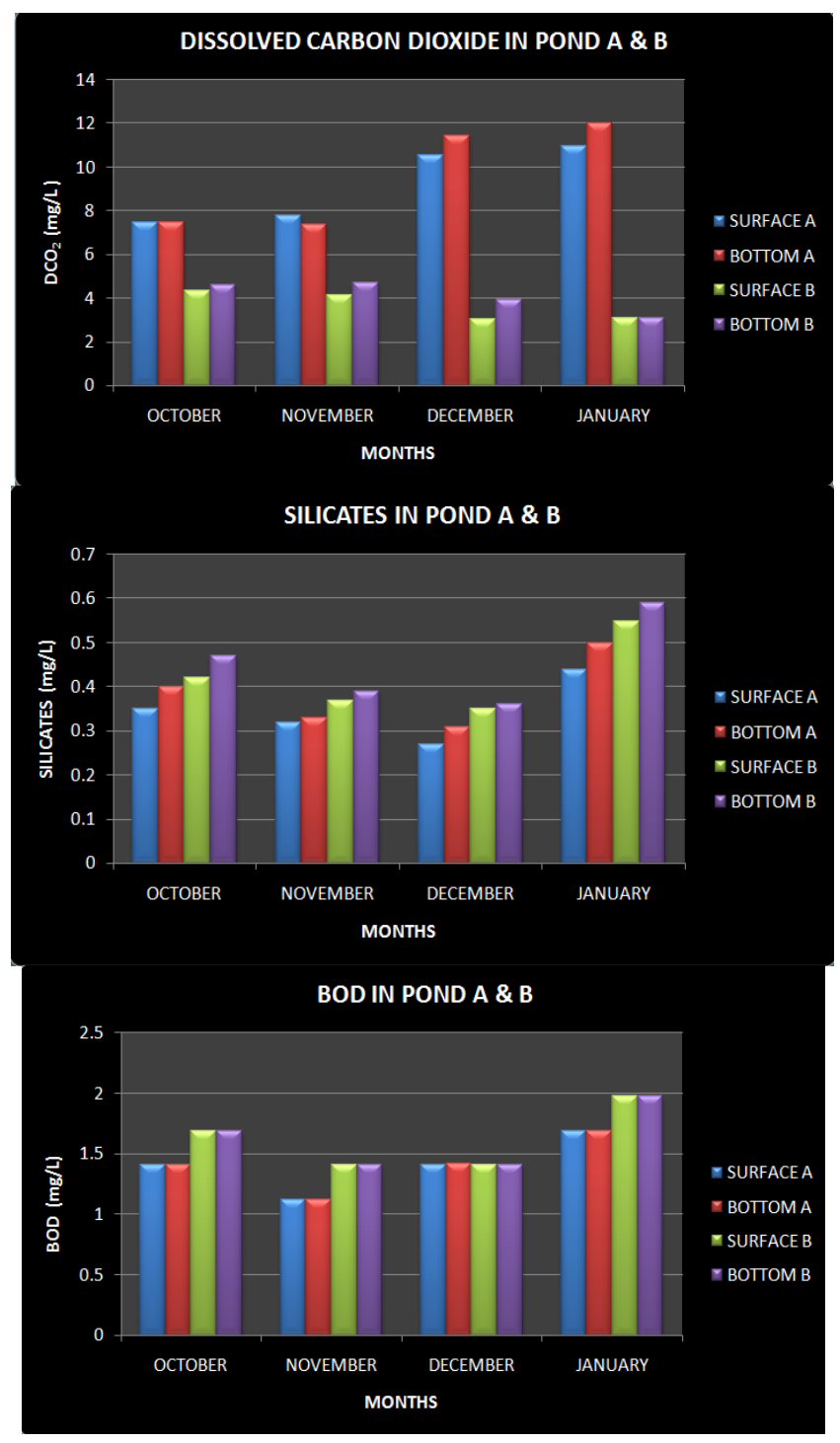

IV. Conclusion

Water temperature was low in both ponds, which showed decrease in temperature level than atmospheric temperature. The concentration of total solid was lower than the maximum permissible limits of ISI and WHO standards in both ponds during the study period. The high content found in the Pond B may be the percolation of wastes in it.The $\mathrm{pH}$ levels were within the permissible. Almost neutral condition was found in both ponds. Dissolved oxygen followed the desirable limit of ISI in both ponds which bared the good quality of pond water having required amount of oxygen for the survival of aquatic organisms.During the study period, little carbon dioxide pollution was observed in Pond B during December which found to be more than the prescribed limit. A slight direct relationship was noted between carbon dioxide and $\mathrm{pH}$. Iron is essential to all organisms and present in haemoglobin system. The iron content was slightly higher in bottom water of pond B during February.The amount of silicates in the water body depends on the amount of biological activity occurring. The values of silicate in both the ponds were found to be low. There is only least biological oxygen demand were observed in both ponds indicating the good quality of water.

Presence of phytoplankton and zooplankton indicating the good quality of the pond, acting as major primary producers in many aquatic systems. Survival of many freshwater fishes is indicating the good quality of water. In the present investigation all the parameters showed higher values in Pond B compared to Pond A. All values are found to be within or less than the permissible limit. Both ponds showed an oligotrophic nature with the presence of poor nutrients and low vegetation. Both ponds are unpolluted fresh water bodies which have no chemical or sewage pollution. Awareness should be created among people in and around villages regarding water pollution and its effects. It is also suggested that all the freshwater ponds should be regularly monitored to preserve and maintain the aquatic systems which would benefit the organisms and their environment. 


\section{References}

[1]. Sukumaran, M., Brinth, M. and Mathavan Pillai. 2008. $\mathrm{P}^{\mathrm{H}}$ Species composition and diversity of phytoplankton of Pechparai dam. India. J. of Ther. And Expl. Bio. 4(4): 157-161.

[2]. Pandey., Ushapandey Tyagi, H. R. and Rai, N. 1998. Algal flora and physico-chemical environment of Fatehsakerlake.Phycos.,37(187): 29-30.

[3]. Wetzel, R. G. 1983.Limnology, $2^{\text {nd }}$ ed.Saunders CO., Philadelphia.

[4]. Kot, B., Baranowski, R. and Rybak, A. 2000.Analysis of mine water using X-ray fluorescence spectrometry. Polish J. Environ, Stud. 9.429.

[5]. Anithakumari, L.R. and Aziz, P.K.A. 1989. Limnology of temple tank in Thiruvananthapuram, Kerala. J.inland fish.Soc. India., 21(2):31-36

[6]. Maya, S., Kumari, S. P. and Menon, S.V. 2001. Quality profile of selected temple tanks of southern Kerala - A study. Proc. $13^{\text {th }}$ Kerala Science Congress, Thrissur. Pp. 511-517.

[7]. Maya, S., Prameela, S. K. and Menon, S. V. 2000. A preliminary study on the algal flora of temple tanks of Southern Kerala. Phycos., 39(1\&2), 77-83.

[8]. Prameela, S. K., Maya, S. and Menon, S.v. 2001. Phytoplankton diversity of temple tanks of four coastal district of Kerala. Proc. $13^{\text {th }}$ Science Congress. Thrissur. pp.203-204.

[9]. Maya, S. 2002. Harvesting water in temple tanks through people's participation. A feasibility study. Nature Environ. Pollut. Tech., 1(4): 375-378.

[10]. APHA . 2005. Standard methods for the examination of water and waste waters, $21^{\text {st }}$ Edn., Washington. DC.USA

[11]. Adoni, A., Joshi, D.G., Gosh, K., Chourasia, S.K., Vaishya, A. K., Manoj Yadav and Verma, H. G. 1985. Work book on limnology. Pratibha Publisher, Sagar.pp. 1-166.

[12]. Agarker, M.S., Goswami, H.K., Kaushik, S., Mishra, S.M., Bajpai, A.K., and Sharma, U.S. 1994. Biology, conservation and management of bhojwtland, upper lake ecosystem in Bhopal. Bionature, 14: 250-273.

[13]. Vasumathi Reddy, K., Laxmiprasad, K., Swamy, M. and Ravinder Reddy, T. 2009.J.Aqua. Biol., $24(1), 1$.

[14]. Shinde, S.E., Pathan, T.S.,Raut, K.S. and Sonawane, D. L. 2011.Middle East J.of Sci. Research.8(3): $544-554$.

[15]. World Health Organization (WHO).1995.Environmental health criteria.5. World Health Organization,Geneva 